\title{
Penerapan Desain Fractional Factorial dalam Menentukan Faktor Berpengaruh pada Eksperimen Pelindian Konsentrat Galena (Pbs)
}

\author{
SRI WINARNII ${ }^{1}$, NENENG SUNENGSIH ${ }^{2}$, REZKY IRIANSYAH ANUGRAH ${ }^{3}$ \\ 1,2Departemen Statistika FMIPA Universitas Padjadjaran \\ 3Puslitbang Teknologi Mineral dan Batubara \\ email: 1sri.winarni@unpad.ac.id, 2nenks.stat@gmail.com, ${ }^{3}$ rezky@tekmira.esdm.go.id
}

\begin{abstract}
ABSTRAK
Desain Fractional Factorial (FF) merupakan desain eksperimen yang mencobakan hanya sebagian perlakuan pada eksperimen banyak faktor. Eksperimen dengan banyak faktor sering kali digunakan pada penelitian bidang pertambangan. Contoh kasus pelindian konsentrat galena (PbS) yang mencobakan enam faktor, yaitu: ukuran partikel, konsentrasi media pelindi, kecepatan pengadukan (stirrer), persen padatan, temperatur, dan waktu pelindian. Dengan desain FF didapatkan hasil tiga alternatif desain FF. Pertama adalah desain FF dengan fraksi setengah $2^{2^{6-1}}$ yang mencobakan 32 kombinasi perlakuan. Kedua dapat juga digunakan desain FF dengan fraksi seperempat $\left(2^{6-2}\right)$ yang mencobakan 16 kombinasi perlakuan. Ketiga adalah desain FF dengan fraksi seperdelapan $2^{6-3}$ yang mencobakan 8 kombinasi perlakuan. Pada contoh analisis didapatkan hasil bahwa faktor yang berpengaruh terhadap persen ekstrak timbal adalah faktor konsentrasi media pelindi, faktor persen padatan dan faktor temperatur.
\end{abstract}

Kata kunci: fractional factorial, fraksi percobaan, generator, resolusi maksimum

\begin{abstract}
Fractional Factorial $(\mathrm{FF})$ design is an experimental design that tries only part of the treatment in the experiment with many factors. Experiments with many factors are often used in mining research. Case examples of galena concentrate $(\mathrm{PbS})$ leaching which tested six factors, namely: particle size, concentration of leachate media, stirrer speed, percent solid, temperature, and leaching time. With the FF design, there are three alternative FF designs. The first is the FF design with a half fraction $2^{6-1}$ which tries 32 combinations of treatments. The second can also be used FF design with a quarter fraction $2^{6-2}$ which tries 16 combinations of treatments. Third is the FF design with an eighth fraction $2^{2^{6-3}}$ which tried 8 combinations of treatments. In the analysis sample, the results show that the factors that influence the percent of lead extract are the factors of the concentration of leachate media, the percent factor of solids and the temperature factor.
\end{abstract}

Keyword: fractional factorial, fraction experiment, generator, maximum resolution

\section{PENDAHULUAN}

Pada penelitian di bidang tambang mineral dan batubara seringkali digunakan eksperimen sebagai prosedur penelitian. Sebuah contoh kasus penelitian di bidang tambang yang dilakukan oleh Puslitbang Mineral Batubara (Tekmira) adalah kasus pelindian konsentrat galena $(\mathrm{PbS})$ dalam asam flosilikat (H2SiF6) dengan oksidator hidragen peroksida (H2O2). Pelindian adalah proses mengekstrak zat yang dapat larut dari padatan menggunakan pelarut. 
Pelindian merupakan proses melarutkan logam yang diinginkan pada konsentrat dalam reagen yang tepat, biasanya juga mengambil logam-logam lain yang ada dalam bijih hingga masuk ke dalam larutan secara bersamaan. Laju pelindian dapat ditentukan setelah mengetahui persen ekstraksi (recovery) sebagai fungsi dari waktu. Laju pelindian bergantung enam faktor, yaitu: ukuran partikel, konsentrasi media pelindi, kecepatan pengadukan (stirrer), persen padatan, temperatur, dan waktu pelindian. Pada kasus ini ingin ditentukan prosedur eksperimen yang tepat sehingga dapat ditentukan faktor yang berpengaruh terhadap persen ekstraksi timbal $(\mathrm{Pb})$.

Pada pelaksanaan penelitian, seringkali muncul pertanyaan bagaimana menentukan prosedur penelitian sehingga didapatkan hasil pengujian yang valid dan informasi yang tepat. Prosedur eksperimen ini meliputi variabel-variabel apa yang terlibat dalam eksperimen, bagaimana melakukan eksperimen, bagaimana mengukur hasil eksperimen, dan bagaimana menganalisis data hasil eksperimen sehingga didapatkan variabel mana yang berpengaruh.

Eksperimen yang mencobakan banyak faktor seperti pada kasus di atas dapat dilakukan dengan cara memecah eksperimen tersebut kedalam beberapa eksperimen. Setiap eksperimen hanya mencobakan dua atau tiga faktor saja. Hanya saja prosedur eksperimen dengan memecah percobaan banyak faktor menjadi beberapa eksperimen dengan dua atau tiga faktor sering kali membawa kesulitan dalam menarik kesimpulan. Akan didapatkan kesimpulan yang bersifat parsial dari masing-masing eksperimen pecahan. Kesimpulan yang didapat dari satu eksperimen belum tentu konsisten dengan kesimpulan yang didapat dari eksperimen yang lain. Untuk itu diperlukan desain eksperimen yang dapat memberikan kesimpulan secara simultan dari keseluruhan faktor percobaan yang terlibat. Desain FF dapat dijadikan alternatif untuk mengetahui pengaruh faktor percobaan dalam jumlah yang besar.

Tujuan penelitian ini adalah memberikan kajian mengenai prosedur dan analisis pada desain FF yang digunakan pada eksperimen banyak faktor. Analisis data diberikan sebagai gambaran bagaimana melakukan analisis pada desain FF.

\section{LANDASAN TEORI}

\section{Apa Itu Desain FF}

Desain FF sering digunakan pada screening experiment, yaitu eksperimen yang dilakukan dengan banyak faktor dan bertujuan untuk mengidentifikasi faktor-faktor mana yang memiliki pengaruh besar. Banyaknya faktor percobaan yang dilibatkan akan membuat ukuran kombinasi perlakuan semakin besar. Sehingga dalam screening experiment seringkali hanya mencobakan dua taraf pada setiap faktornya, yaitu taraf tinggi dan taraf rendah. Faktor-faktor yang berhasil diidentifikasi memiliki pengaruh besar akan dinvestigasi lebih lanjut pada percobaan lanjutan dengan melibatkan lebih banyak taraf faktor. Vijay et.all, (2008).

Desain FF merupakan desain eksperimen yang hanya mencobakan sebagian dari kombinasi perlakuan lengkap. Pada desain FF, walaupun hanya mencobakan sebagian kombinasi perlakuan lengkap, tetapi informasi mengenai pengaruh faktor utama tetap didapatkan. Pembentukan desain FF dilakukan dengan mempertimbangkan beberapa hal, yaitu: fraksi percobaan, generator, defining relation, dan alias. Desain FF dengan $n$ faktor dalam dua taraf dinotasikan dengan $2^{n-p}$. Box $\&$ Hunter (1961).

\section{Fraksi Percobaan}

Fraksi percobaan merupakan proporsi kombinasi perlakuan yang akan dicobakan, atau berapa bagian dari kombinasi perlakuan lengkap yang akan dicobakan. Fraksi yang diambil bisa fraksi $1 / 2$, fraksi $1 / 4$, fraksi $1 / 8$, dan seterusnya. Secara umum dapat dituliskan dengan fraksi $1 / 2^{p}$. Mengambil fraksi $1 / 2$ artinya mencobakan hanya setengah dari kombinasi perlakuan lengkap. Jika eksperimen melibatkan empat faktor dengan masing-masing dua taraf maka hanya delapan perlakuan yang dicobakan dari enam belas kombinasi perlakuan lengkap. Montgomery (1997).

Statistika, Vol. 19, No. 2, November 2019 


\section{Generator dan Defining Relation}

Generator dan defining relation merupakan penentu dalam pembentukan desain FF. Generator dibangkitkan dari kombinasi faktor sedemikian rupa sehingga hasil dari perlakuan yang dicobakan tetap dapat memberikan informasi mengenai pengaruh utama faktor. Defining relation merupakan hubungan identitas dari generator. Pembentukan generator dilakukan sedemikian rupa sehingga menghasilkan struktur desain yang terbaik, yaitu yang mampu menduga pengaruh utama faktor dan menduga pengaruh interaksi tingkat rendah. Montgomery (1997).

\section{Alias dan Resolusi}

Penggunaan desain FF yang hanya mencobakan sebagian dari kombinasi perlakuan lengkap mengakibatkan adanya pengaruh faktor dan interaksi yang saling berbaur (confounded). Hubungan pendugaan pengaruh faktor yang saling berbaur disebut dengan alias. Dua pengaruh faktor yang berbaur tidak dapat diduga satu sama lain kecuali salah satu pengaruh diabaikan. struktur alias didapatkan dari perkalian pengaruh faktor dengan defining relation. Struktur defining relation yang berbeda akan menghasilkan struktur alias yang berbeda. Box $\&$ Hunter (1961)

Resolusi merupakan panjang terpendek dari defining relation. Sebuah desain FF dengan Resolusi III akan mengakibatkan pengaruh faktor utama berbaur dengan interaksi dua faktor atau lebih. Sebuah desain FF dengan Resolusi IV akan mengakibatkan pengaruh faktor utama berbaur dengan interaksi tiga faktor atau lebih, dan interaksi dua faktor akan berbaur dengan interaksi dua faktor atau lebih. Sebuah desain FF dengan Resolusi VI akan mengakibatkan pengaruh faktor utama berbaur dengan interaksi lima faktor atau lebih, interaksi dua faktor akan berbaur dengan interaksi empat faktor atau lebih, dan interaksi tiga faktor akan berbaur dengan interaksi tiga faktor atau lebih. Pengaruh faktor utama lebih dipentingkan daripada pengaruh interaksi. Pengaruh interaksi dua faktor lebih dipentingkan daripada interaksi tiga faktor atau lebih. Dengan demikian kriteria pembentukan struktur desain FF terbaik pada fraksi yang digunakan adalah desain yang memiliki Resolusi maksimum. Montgomery (1997)

\section{Efek Faktor dan Anova}

Efek faktor digunakan untuk mengetahui seberapa besar pengaruh faktor tersebut terhadap respon. Pengaruh (efek) faktor didapatkan dari Persamaan 1.

efek faktor $=\frac{2}{n 2^{k}}$ (kontras $A, B, \ldots$ )

Kontras merupakan perkalian nilai amatan dengan nilai kontras perlakuan. Efek faktor dapat bernilai positif atau negatif. Nilai positif artinya pengaruh taraf tinggi faktor lebih besar dari taraf rendah faktor. Nilai negatif sebaliknya, pengaruh taraf tinggi faktor lebih kecil daripada taraf rendah faktor. Tanda positif dan negatif ini tidak mempengaruhi besarnya efek. Faktor dengan efek besar akan masuk dalam komponen sumber keragaman pada anova dan faktor yang memiliki efek relatif kecil menjadi komponen eror. Anova merupakan alat analisis yang memecah komponen keragaman respon menjadi komponen keragaman faktor-faktornya. Pada anova, jumlah kuadrat pada anova didapatkan dari Persamaan 2.

Jumlah kuadrat $=\frac{1}{m 2^{k}}(\text { kontras } A, B, \ldots k)^{2}$

Kedua persamaan di atas merupakan bentuk umum dari persamaan efek faktor dan jumlah kuadrat pada anova. Pada output anova terdapat P-value, jika P-value < 0,05 (alpha) maka faktor berpengaruh terhadap respon. Montgomery (1997)

\section{METODOLOGI PENELITIAN}

Pembentukan desain FF dimulai dari penentuan faktor dan taraf yang dicobakan. Pada contoh kasus yang dibahas dalam penelitian ini terdapat enam faktor percobaan yang akan diketahui pengaruhnya terhadap persen ekstraksi timbal. Keenam faktor tersebut dibentuk masingmasing dalam dua taraf, yaitu taraf tinggi dan taraf rendah. Faktor dan taraf percobaan diberikan pada Tabel 1 . 
Tabel 1. Faktor dan Taraf Percobaan

\begin{tabular}{lll}
\hline \multirow{2}{*}{ Faktor Percobaan } & \multicolumn{2}{c}{ Taraf } \\
\cline { 2 - 3 } & \multicolumn{1}{c}{ Rendah (-1) } & \multicolumn{1}{c}{ Tinggi (1) } \\
\hline A : Ukuran partikel & $-100+150$ mesh & $-325+400$ mesh \\
B : Konsentrasi media pelindi & $0,5 \mathrm{M}$ & $3,44 \mathrm{M}$ \\
C : Kecepatan pengadukan & $100 \mathrm{rpm}$ & $700 \mathrm{rpm}$ \\
D : Persen padatan & $9 \%$ & $29 \%$ \\
E : Temperature & $50 \circ \mathrm{C}$ & $97 \circ \mathrm{C}$ \\
F : Waktu pelindian & 5 menit & 150 menit \\
\hline
\end{tabular}

Terdapat enam faktor dalam dua taraf yang terlibat dalam percobaan. Jika digunakan desain faktorial lengkap maka akan ada $2^{6}=64$ kombinasi perlakuan yang dicobakan. Jumlah ini terlalu besar untuk dilakukan. Dengan desain FF hanya dilakukan sebagian kombinasi perlakuan.

Pembentukan kombinasi perlakuan yang dicobakan pada desain FF dilakukan dengan menetukan terlebih dahulu fraksi yang akan digunakan. Jika digunakan fraksi setengah maka kombinasi perlakuan yang dicobakan sebanyak $1 / 2 \times 64=2^{6-1}=32$. Jika digunakan fraksi seperempat maka kombinasi perlakuan yang dicobakan sebanyak $1 / 4 \times 64=2^{6-2}=16$. Dan jika digunakan fraksi seperdelapan maka kombinasi perlakuan yang dicobakan sebanyak $1 / 8 \times 64=2^{6-a}=8$. Penggunaan fraksi percobaan ini didasarkan oleh pertimbangan peneliti terkait biaya penelitian dan sebagainya. Selanjutnya akan dibahas bagaimana penggunaan ketiga alternatif fraksi percobaan tersebut. Chen (1993).

\section{HASIL DAN PEMBAHASAN}

\section{Hasil Pembentukan Desain FF $2^{6-1}$}

Desain $\mathrm{FF} 2^{6-1}$ merupakan desain $\mathrm{FF} 6$ faktor dalam dua taraf, dan fraksi setengah. Jika digunakan fraksi setengah maka terdapat 32 kombinasi perlakuan yang dicobakan. Pembentukan kombinasi perlakuan tersebut dilakukan dengan menetapkan generator yang dapat membentuk struktur perlakuan terbaik. Pada fraksi setengah, generator yang dibentuk adalah generator dengan struktur faktor terpanjang. Pada kasus ini diambil struktur generator $\mathrm{F}=\mathrm{ABCDE}$, artinya bahwa taraf faktor $\mathrm{F}$ dibentuk dari kombinasi linear faktor $\mathrm{A}, \mathrm{B}, \mathrm{C}, \mathrm{D}$ dan E. Defining relation yang terbentuk adalah $\mathrm{I}=\mathrm{ABCDEF}$. Defining relation ini didapatkan dari mengalikan generator dengan faktor generator-nya. Generator F = ABCDE dikalikan dengan $\mathrm{F}$ didapatkan $\mathrm{FF}=\mathrm{ABCDEF}$ menjadi $\mathrm{I}=\mathrm{ABCDEF}$. Dengan defining relation tersebut didapatkan struktur alias yang diberikan pada Tabel 2.

Tabe1 2. Struktur Alias untuk Desain Fractional Factorial $2^{6-1}$

\begin{tabular}{llll}
\hline \multicolumn{4}{c}{ Alias } \\
\hline $\mathbf{A}+\mathrm{BCDEF}$ & $\mathbf{A D}+\mathrm{BCEF}$ & $\mathbf{C E}+\mathrm{ABDF}$ & $\mathbf{A B F}+\mathrm{CDE}$ \\
$\mathbf{B}+\mathrm{ACDEF}$ & $\mathbf{A E}+\mathrm{BCDF}$ & $\mathbf{C F}+\mathrm{ABDE}$ & $\mathbf{A C D}+\mathrm{BEF}$ \\
$\mathbf{C}+\mathrm{ABDEF}$ & $\mathbf{A F}+\mathrm{BCDE}$ & $\mathbf{D E}+\mathrm{ABCF}$ & $\mathbf{A C E}+\mathrm{BDF}$ \\
$\mathbf{D}+\mathrm{ABCEF}$ & $\mathbf{B C}+\mathrm{ADEF}$ & $\mathbf{D F}+\mathrm{ABCE}$ & $\mathbf{A C F}+\mathrm{BDE}$ \\
$\mathbf{E}+\mathrm{ABCDF}$ & $\mathbf{B D}+\mathrm{ACEF}$ & $\mathbf{E F}+\mathrm{ABCD}$ & $\mathbf{A D E}+\mathrm{BCF}$ \\
$\mathbf{F}+\mathrm{ABCDE}$ & $\mathbf{B E}+\mathrm{ACDF}$ & $\mathbf{A B C}+\mathrm{DEF}$ & $\mathbf{A D F}+\mathrm{BCE}$ \\
$\mathbf{A B}+\mathrm{CDEF}$ & $\mathbf{B F}+\mathrm{ACDE}$ & $\mathbf{A B D}+\mathrm{CEF}$ & $\mathbf{A E F}+\mathrm{BCD}$ \\
$\mathbf{A C}+\mathrm{BDEF}$ & $\mathbf{C D}+\mathrm{ABEF}$ & $\mathbf{A B E}+\mathrm{CDF}$ & \\
\hline
\end{tabular}

Statistika, Vol. 19, No. 2, November 2019 
Pada Tabel 2 didapatkan 31 struktur alias, artinya terdapat 31 pengaruh faktor dapat diduga. Struktur alias A + BCDEF didapatkan dari mengalikan defining relation dengan faktor A, yaitu $\mathrm{AI}=\mathrm{AABCDEF}$ menjadi $\mathrm{A}=\mathrm{BCDEF}$, dinotasikan dengan $\mathrm{A}+\mathrm{BCDEF}$. Struktur alias $\mathrm{A}+\mathrm{BCDEF}$ artinya bahwa pengaruh faktor utama A ber-confounded (berbaur) dengan pengaruh interaksi BCDEF. Hal ini berarti bahwa pengaruh utama faktor A dan pengaruh interaksi BCDEF tidak dapat diduga satu sama lain, kecuali salah satu pengaruh tersebut diabaikan. dengan demikian pengaruh utama faktor A dapat diduga dengan mengabaikan pengaruh interaksi BCDEF (dianggap nol). Begitu juga untuk struktur alias yang lain. Dengan mengambil fraksi setengah dapat diduga 31 pengaruh faktor, terdiri dari 6, 15, dan 6 berturut-turut untuk pengaruh utama faktor, pengaruh interaksi dua faktor, dan pengaruh interaksi dua faktor.

Pada desain $\mathrm{FF} 2^{6-1}$ dengan defining relation $\mathrm{I}=\mathrm{ABCDEF}$ akan terbentuk Resolusi VI. Pada struktur alias (Tabel 2) didapatkan bahwa pengaruh faktor utama berbaur dengan pengaruh interaksi lima faktor, pengaruh interaksi dua faktor berbaur dengan pengaruh interaksi empat faktor dan pengaruh interaksi tiga faktor akan berbaur dengan pengaruh interaksi tiga faktor. Karena yang dipentingkan adalah menduga pengaruh faktor utama dan pengaruh interaksi tingkat rendah maka pada Tabel 2 pengaruh faktor yang akan diduga adalah pengaruh faktor yang dicetak tebal.

Hasil selanjutnya adalah struktur desain yang terdiri dari kombinasi perlakuan yang akan dicobakan. Tiga puluh dua kombinasi perlakuan yang dicobakan didapatkan dari struktur generator terbaik yang dihasilkan, yaitu $F=$ ABCDE. Struktur perlakuan yang didapat diberikan pada Tabel 3.

Tabel 3. Struktur Perlakuan untuk Desain FF $2^{6-1}$

\begin{tabular}{ccccccc}
\hline & \multicolumn{5}{c}{ Faktor } \\
\cline { 2 - 7 } & A & B & C & D & E & $\begin{array}{c}\text { F }= \\
\text { ABCDE }\end{array}$ \\
\hline 1 & -1 & -1 & -1 & -1 & -1 & -1 \\
2 & 1 & -1 & -1 & -1 & -1 & 1 \\
3 & -1 & 1 & -1 & -1 & -1 & 1 \\
4 & 1 & 1 & -1 & -1 & -1 & -1 \\
5 & -1 & -1 & 1 & -1 & -1 & 1 \\
6 & 1 & -1 & 1 & -1 & -1 & -1 \\
7 & -1 & 1 & 1 & -1 & -1 & -1 \\
8 & 1 & 1 & 1 & -1 & -1 & 1 \\
9 & -1 & -1 & -1 & 1 & -1 & 1 \\
10 & 1 & -1 & -1 & 1 & -1 & -1 \\
11 & -1 & 1 & -1 & 1 & -1 & -1 \\
12 & 1 & 1 & -1 & 1 & -1 & 1 \\
13 & -1 & -1 & 1 & 1 & -1 & -1 \\
14 & 1 & -1 & 1 & 1 & -1 & 1 \\
15 & -1 & 1 & 1 & 1 & -1 & 1 \\
16 & 1 & 1 & 1 & 1 & -1 & -1 \\
\hline
\end{tabular}

\begin{tabular}{ccccccc}
\hline & \multicolumn{5}{c}{ Faktor } \\
\cline { 2 - 7 } No & A & B & C & D & E & $\begin{array}{c}\text { F }= \\
\text { ABCDE }\end{array}$ \\
\hline 17 & -1 & -1 & -1 & -1 & 1 & 1 \\
18 & 1 & -1 & -1 & -1 & 1 & -1 \\
19 & -1 & 1 & -1 & -1 & 1 & -1 \\
20 & 1 & 1 & -1 & -1 & 1 & 1 \\
21 & -1 & -1 & 1 & -1 & 1 & -1 \\
22 & 1 & -1 & 1 & -1 & 1 & 1 \\
23 & -1 & 1 & 1 & -1 & 1 & 1 \\
24 & 1 & 1 & 1 & -1 & 1 & -1 \\
25 & -1 & -1 & -1 & 1 & 1 & -1 \\
26 & 1 & -1 & -1 & 1 & 1 & 1 \\
27 & -1 & 1 & -1 & 1 & 1 & 1 \\
28 & 1 & 1 & -1 & 1 & 1 & -1 \\
29 & -1 & -1 & 1 & 1 & 1 & 1 \\
30 & 1 & -1 & 1 & 1 & 1 & -1 \\
31 & -1 & 1 & 1 & 1 & 1 & -1 \\
32 & 1 & 1 & 1 & 1 & 1 & 1 \\
\hline & & & & & &
\end{tabular}

Pada Tabel 3 didapatkan 32 struktur kombinasi perlakuan untuk desain $\mathrm{FF} 2^{6-1}$. Terdapat lima faktor yang menjadi faktor dasar, yaitu faktor A, B, C, D dan E. Struktur faktor dasar memiliki pola yang teratur. Pada faktor A taraf faktor berpola (-1) dan (1) secara bergantian. Faktor B memiliki pola dua (-1) dan dua (1) secara bergantian. Faktor C berpola empat bergantian, faktor $\mathrm{D}$ delapan bergantian dan faktor $\mathrm{E}$ enam belas bergantian. Faktor $\mathrm{F}$ menjadi faktor generator $\mathrm{F}$ $=\mathrm{ABCDE}$ yang merupakan perkalian dari taraf faktor $\mathrm{A}, \mathrm{B}, \mathrm{C}, \mathrm{D}$ dan $\mathrm{E}$. 
Pada perlakuan 1 berarti bahwa perlakuan yang dicobakan adalah faktor A taraf rendah (100+150 mesh), faktor B taraf rendah $(0,5 \mathrm{M})$, faktor C taraf rendah (100 rpm), faktor D taraf rendah $(9 \%)$, faktor $\mathrm{E}$ taraf rendah $\left(50^{\circ} \mathrm{C}\right)$, dan faktor $\mathrm{F}$ taraf rendah (5 menit). Pada perlakuan 2 dicobakan faktor A taraf tinggi $(-325+400 \mathrm{mesh})$, faktor B taraf rendah $(0,5 \mathrm{M})$, faktor $\mathrm{C}$ taraf rendah $(100 \mathrm{rpm})$, faktor $\mathrm{D}$ taraf rendah $(9 \%)$, faktor $\mathrm{E}$ taraf rendah $\left(50{ }^{\circ} \mathrm{C}\right)$, dan faktor $\mathrm{F}$ taraf tinggi (150 menit), begitu seterusnya sampai perlakuan 32 .

\section{Hasil Pembentukan Desain FF $2^{6-2}$}

Desain $\mathrm{FF} 2^{6-2}$ merupakan desain $\mathrm{FF} 6$ faktor dalam dua taraf, dan fraksi seperempat. Jika digunakan fraksi seperempat maka terdapat 16 kombinasi perlakuan yang dicobakan. Untuk membentuk fraksi seperempat dibutuhkan dua generator untuk membentuk struktur perlakuannya. Dengan bantuan Minitab didapatkan output generator terbaik adalah $\mathrm{E}=\mathrm{ABC}$ dan $\mathrm{F}=\mathrm{BCD}$. Dengan demikian defining relation yang dihasilkan adalah $\mathrm{I}=\mathrm{ABCE}=\mathrm{BCDF}=$ ADEF. Defining relation ADEF didapatkan dari perkalian defining relation $\mathrm{ABCE}$ dan $\mathrm{BCDF}$, yaitu ABCEBCDF menjadi ADEF. Resolusi yang dihasilkan dari struktur desain ini adalah Resolusi IV. Struktur defining relation ini menghasilkan struktur alias yang diberikan pada Tabel 4.

Tabel 4. Struktur Alias untuk Desain Fractional Factorial $2^{6-2}$

\begin{tabular}{ll}
\hline & Alias \\
\hline $\mathbf{A}+\mathrm{BCE}+\mathrm{DEF}+\mathrm{ABCDF}$ & $\mathbf{A D}+\mathbf{E F}+\mathrm{ABCF}+\mathrm{BCDE}$ \\
$\mathbf{B}+\mathrm{ACE}+\mathrm{CDF}+\mathrm{ABDEF}$ & $\mathbf{A E}+\mathbf{B C}+\mathbf{D F}+\mathrm{ABCDEF}$ \\
$\mathbf{C}+\mathrm{ABE}+\mathrm{BDF}+\mathrm{ACDEF}$ & $\mathbf{A F}+\mathbf{D E}+\mathrm{ABCD}+\mathrm{BCEF}$ \\
$\mathbf{D}+\mathrm{AEF}+\mathrm{BCF}+\mathrm{ABCDE}$ & $\mathbf{B D}+\mathbf{C F}+\mathrm{ABEF}+\mathrm{ACDE}$ \\
$\mathbf{E}+\mathrm{ABC}+\mathrm{ADF}+\mathrm{BCDEF}$ & $\mathbf{B F}+\mathbf{C D}+\mathrm{ABDE}+\mathrm{ACEF}$ \\
$\mathbf{F}+\mathrm{ADE}+\mathrm{BCD}+\mathrm{ABCEF}$ & $\mathbf{A B D}+\mathrm{ACF}+\mathrm{BEF}+\mathrm{CDE}$ \\
$\mathbf{A B}+\mathbf{C E}+\mathrm{ACDF}+\mathrm{BDEF}$ & $\mathbf{A B F}+\mathrm{ACD}+\mathrm{BDE}+\mathrm{CEF}$ \\
$\mathbf{A C}+\mathbf{B E}+\mathrm{ABDF}+\mathrm{CDEF}$ & \\
\hline
\end{tabular}

Tabel 5. Struktur Perlakuan untuk Desain FF $2^{6-2}$

\begin{tabular}{ccccccc}
\hline & \multicolumn{6}{c}{ Faktor } \\
\cline { 2 - 7 } & A & B & C & D & $\begin{array}{c}\text { E }= \\
\text { ABC }\end{array}$ & F $=$ \\
& & & & & BCD \\
\hline 1 & -1 & -1 & -1 & -1 & -1 & -1 \\
2 & 1 & -1 & -1 & -1 & 1 & -1 \\
3 & -1 & 1 & -1 & -1 & 1 & 1 \\
4 & 1 & 1 & -1 & -1 & -1 & 1 \\
5 & -1 & -1 & 1 & -1 & 1 & 1 \\
6 & 1 & -1 & 1 & -1 & -1 & 1 \\
7 & -1 & 1 & 1 & -1 & -1 & -1 \\
8 & 1 & 1 & 1 & -1 & 1 & -1 \\
\hline
\end{tabular}

\begin{tabular}{ccccccc}
\hline No & \multicolumn{6}{c}{ Faktor } \\
\cline { 2 - 7 } & A & B & C & D & $\begin{array}{c}\mathrm{E}= \\
\text { ABC }\end{array}$ & $\begin{array}{c}\text { F }= \\
\text { BCD }\end{array}$ \\
\hline 9 & -1 & -1 & -1 & 1 & -1 & 1 \\
10 & 1 & -1 & -1 & 1 & 1 & 1 \\
11 & -1 & 1 & -1 & 1 & 1 & -1 \\
12 & 1 & 1 & -1 & 1 & -1 & -1 \\
13 & -1 & -1 & 1 & 1 & 1 & -1 \\
14 & 1 & -1 & 1 & 1 & -1 & -1 \\
15 & -1 & 1 & 1 & 1 & -1 & 1 \\
16 & 1 & 1 & 1 & 1 & 1 & 1 \\
\hline
\end{tabular}


Pada Tabel 4 didapatkan bahwa pengaruh faktor utama beralias dengan interaksi tiga faktor atau lebih, pengaruh interaksi dua faktor beralias dengan interaksi dua faktor atau lebih. Dengan 16 kombinasi perlakuan yang dicobakan dapat diduga 15 pengaruh faktor yang terdiri dari 6 pengaruh faktor utama, 7 pengaruh interaksi dua faktor dan 2 pengaruh interaksi tiga faktor. Pengaruh interaksi $\mathrm{AB}$ beralias dengan pengaruh interaksi CE, ACDF dan BDEF. Artinya bahwa keempat pengaruh faktor tersebut saling berbaur, pengaruh interaksi $A B$ dapat diduga dengan mengabaikan pengaruh interaksi $\mathrm{CE}$, ACDF dan BDEF. Jika yang ingin diduga adalah pengaruh interaksi $\mathrm{CE}$ maka pengaruh interaksi $\mathrm{AB}, \mathrm{ACDF}$ dan BDEF dapat diabaikan.

Output utama dari pembentukan struktur desain ini adalah struktur kombinasi perlakuan yang dicobakan. Struktur ini ditentukan oleh dua generator yang terbentuk, yaitu $\mathrm{E}=\mathrm{ABC}$ dan $\mathrm{F}=\mathrm{BCD}$. Struktur kombinasi perlakuan yang terbentuk diberikan pada Tabel 5. Terdapat 16 kombinasi perlakuan yang terbentuk. Faktor A, B, C, dan D merupakan faktor dasar yang memiliki bentuk teratur. Faktor $\mathrm{E}$ dan $\mathrm{F}$ merupakan faktor generator, $\mathrm{E}=\mathrm{ABC}$ dan $\mathrm{F}=\mathrm{BCD}$. Pada perlakuan no 1 keenam faktor dicobakan pada taraf rendah, dan pada perlakuan no 16 keenam faktor dicobakan pada taraf tinggi.

Tabe1 6. Struktur Alias untuk Desain FF $2^{6-a}$

\begin{tabular}{c} 
Alias \\
\hline $\mathbf{A}+\mathrm{BD}+\mathrm{CE}+\mathrm{BEF}+\mathrm{CDF}+\mathrm{ABCF}+\mathrm{ADEF}+\mathrm{ABCDE}$ \\
$\mathbf{B}+\mathrm{AD}+\mathrm{CF}+\mathrm{AEF}+\mathrm{CDE}+\mathrm{ABCE}+\mathrm{BDEF}+\mathrm{ABCDF}$ \\
$\mathbf{C}+\mathrm{AE}+\mathrm{BF}+\mathrm{ADF}+\mathrm{BDE}+\mathrm{ABCD}+\mathrm{CDEF}+\mathrm{ABCEF}$ \\
$\mathbf{D}+\mathrm{AB}+\mathrm{EF}+\mathrm{ACF}+\mathrm{BCE}+\mathrm{ACDE}+\mathrm{BCDF}+\mathrm{ABDEF}$ \\
$\mathbf{E}+\mathrm{AC}+\mathrm{DF}+\mathrm{ABF}+\mathrm{BCD}+\mathrm{ABDE}+\mathrm{BCEF}+\mathrm{ACDEF}$ \\
$\mathbf{F}+\mathrm{BC}+\mathrm{DE}+\mathrm{ABE}+\mathrm{ACD}+\mathrm{ABDF}+\mathrm{ACEF}+\mathrm{BCDEF}$ \\
$\mathbf{A F}+\mathbf{B E}+\mathbf{C D}+\mathrm{ABC}+\mathrm{ADE}+\mathrm{BDF}+\mathrm{CEF}+\mathrm{ABCDEF}$ \\
\hline
\end{tabular}

Tabe1 7. Struktur Perlakuan untuk Desain FF $2^{6-a}$

\begin{tabular}{ccccccc}
\hline No & \multicolumn{7}{c}{ Faktor } \\
\cline { 2 - 7 } & A & B & C & D = AB & E = AC & F = BC \\
\hline 1 & -1 & -1 & -1 & 1 & 1 & 1 \\
2 & 1 & -1 & -1 & -1 & -1 & 1 \\
3 & -1 & 1 & -1 & -1 & 1 & -1 \\
4 & 1 & 1 & -1 & 1 & -1 & -1 \\
5 & -1 & -1 & 1 & 1 & -1 & -1 \\
6 & 1 & -1 & 1 & -1 & 1 & -1 \\
7 & -1 & 1 & 1 & -1 & -1 & 1 \\
8 & 1 & 1 & 1 & 1 & 1 & 1 \\
\hline
\end{tabular}

\section{Hasil Pembentukan Desain FF $2^{6-3}$}

Desain $\mathrm{FF} 2^{6-a}$ merupakan desain FF 6 faktor dalam dua taraf, dan fraksi seperdelapan. Jika digunakan fraksi seperdelapan maka terdapat 8 kombinasi perlakuan yang dicobakan. Untuk membentuk fraksi seperdelapan dibutuhkan tiga generator untuk membentuk struktur perlakuannya. Dengan bantuan Minitab didapatkan tiga generator, yaitu $D=A B, E=A C$, dan $F$ $=\mathrm{BC}$. Sehingga defining relation yang terbentuk adalah $\mathrm{I}=\mathrm{ABD}=\mathrm{ACE}=\mathrm{BCF}=\mathrm{BCDE}=\mathrm{ACDF}$ $=\mathrm{ABEF}=\mathrm{DEF}$. Resolusi yang dihasilkan adalah Resolusi III, struktur alias yang dihasilkan diberikan pada Tabel 6. 
Pada Tabel 6 didapatkan bahwa pengaruh faktor utama beralias dengan pengaruh interaksi dua faktor atau lebih, dengan demikian interaksi dua faktor tidak dapat diduga. Interaksi dua faktor yang dapat diduga adalah satu diantara pengaruh $\mathrm{AF}$, BE, atau CD. Struktur kombinasi perlakuan yang dihasilkan diberikan pada Tabel 7. Faktor A, B dan C menjadi faktor dasar dan faktor D, E, F menjadi faktor generator. Pada kombinasi perlakuan no 8 semua faktor dicobakan pada taraf tinggi. Dengan mencobakan delapan kombinasi perlakuan pada Tabel 7 dapat diduga enam pengaruh faktor utama, dan hanya satu saja pengaruh interaksi dua faktor yang dapat diduga. Tiga kemungkinan struktur desain FF untuk enam faktor dalam dua taraf sudah dibahas. Berikutnya adalah bagaimana menganalisis hasil percobaan pada desain FF sehingga dapat diketahui faktor mana yang berpengaruh.

\section{Hasil Analisis pada Desain FF}

Analisis pada desain FF dilakukan untuk mengetahui faktor mana yang berpengaruh dari beberapa faktor yang dicobakan. Untuk keperluan ini maka diperlukan ilustrasi kasus data percobaan yang ditujukan untuk memberi kajian bagaimana melakukan analisis data hasil percobaan pada desain FF. Pada penelitian ini akan dikaji analisis data untuk desain FF fraksi seperempat $2^{6-2}$. Desain ini dipilih dengan alasan bahwa informasi penting mengenai pengaruh faktor utama dan interaksi dua faktor dapat diduga. Struktur kombinasi perlakuan didasarkan pada Tabel 5. Ilustrasi data hasil percobaan diberikan pada Tabel 8.

Tabe1 8. Ilustrasi Data Hasil Percobaan Desain FF $2^{6-2}$

\begin{tabular}{|c|c|c|c|c|c|c|c|}
\hline \multirow{2}{*}{ No } & \multicolumn{6}{|c|}{ Faktor } & \multirow{2}{*}{$\mathrm{Pb}(\%)$} \\
\hline & A & B & $\mathrm{C}$ & $\mathrm{D}$ & $\mathrm{E}$ & $\mathrm{F}$ & \\
\hline 1 & -1 & -1 & -1 & -1 & -1 & -1 & 25,12 \\
\hline 2 & 1 & -1 & -1 & -1 & 1 & -1 & 52,15 \\
\hline 3 & -1 & 1 & -1 & -1 & 1 & 1 & 52,21 \\
\hline 4 & 1 & 1 & -1 & -1 & -1 & 1 & 52,19 \\
\hline 5 & -1 & -1 & 1 & -1 & 1 & 1 & 46,81 \\
\hline 6 & 1 & -1 & 1 & -1 & -1 & 1 & 47,47 \\
\hline 7 & -1 & 1 & 1 & -1 & -1 & -1 & 45,63 \\
\hline 8 & 1 & 1 & 1 & -1 & 1 & -1 & 65,58 \\
\hline
\end{tabular}

\begin{tabular}{cccccccc}
\hline \multirow{2}{*}{ No } & \multicolumn{7}{c}{ Faktor } \\
\cline { 2 - 6 } & $\mathrm{A}$ & $\mathrm{B}$ & $\mathrm{C}$ & $\mathrm{D}$ & $\mathrm{E}$ & $\mathrm{F}$ & $\mathrm{Pb}(\%)$ \\
\hline 9 & -1 & -1 & -1 & 1 & -1 & 1 & 54,37 \\
10 & 1 & -1 & -1 & 1 & 1 & 1 & 78,36 \\
11 & -1 & 1 & -1 & 1 & 1 & -1 & 74,19 \\
12 & 1 & 1 & -1 & 1 & -1 & -1 & 63,52 \\
13 & -1 & -1 & 1 & 1 & 1 & -1 & 68,62 \\
14 & 1 & -1 & 1 & 1 & -1 & -1 & 52,71 \\
15 & -1 & 1 & 1 & 1 & -1 & 1 & 83,21 \\
16 & 1 & 1 & 1 & 1 & 1 & 1 & 85,36 \\
\hline
\end{tabular}

Dari 16 kombinasi perlakuan pada Tabel 8 dapat diduga 15 pengaruh faktor yang diberikan pada Tabel 4. Dengan menggunakan Persamaan 1 didapatkan efek faktor terhadap persen ekstraksi timbal. Dengan bantuan Minitab didapatkan hasil 15 efek faktor yang diberikan pada Tabel 9.

Tabe1 9. Efek Faktor untuk Ilustrasi Data Percobaan pada Tabel 8

\begin{tabular}{rlclll}
\hline \multicolumn{5}{c}{ Efek Faktor } \\
\hline $\mathrm{A}=5,897$ & $\mathrm{AD}$ & $=$ & $-6,007$ \\
$\mathrm{~B}$ & $=12,035$ & $\mathrm{AE}$ & $=$ & 4,008 \\
$\mathrm{C}$ & $=5,410$ & $\mathrm{AF}$ & $=$ & 0,798 \\
$\mathrm{D}$ & $=21,647$ & $\mathrm{BD}$ & $=$ & 1,020 \\
$\mathrm{E}$ & $=12,383$ & $\mathrm{BF}$ & $=$ & $-0,545$ \\
$\mathrm{~F}$ & $=6,557$ & $\mathrm{ABD}$ & $=$ & $-1,105$ \\
$\mathrm{AB}$ & $=-3,045$ & $\mathrm{ABF}$ & $=$ & $-2,585$ \\
$\mathrm{AC}$ & $=$ & & & \\
\hline
\end{tabular}

Statistika, Vol. 19, No. 2, November 2019 
Pada Tabel 9 terlihat bahwa faktor utama yang memiliki pengaruh yang relative besar. Pengaruh interaksi dua dan tiga faktor memiliki efek yang relative kecil. Pengujian pengaruh faktor akan dilakukan dengan anova dengan pengaruh faktor utama sebagai komponen keragaman dan pengaruh faktor yang memiliki efek relatif kecil dimasukkan sebagai komponen eror. Perhitungan jumlah kuadrat anova dapat dilakukan dengan Persamaan 2. Hasil anova diberikan pada Tabel 10.

Tabe1 10. Analisis ANOVA untuk Ilustrasi Data Percobaan pada Tabel 8

\begin{tabular}{ccrrrr}
\hline $\begin{array}{c}\text { Sumber } \\
\text { Keragaman }\end{array}$ & $\begin{array}{c}\text { Derajat } \\
\text { bebas }\end{array}$ & $\begin{array}{l}\text { Jumlah } \\
\text { Kuadrat }\end{array}$ & $\begin{array}{l}\text { Kuadrat } \\
\text { Tengah }\end{array}$ & F-Hitung & P-Value \\
\hline A & 1 & 139,1 & 139,1 & 3,52 & 0,093 \\
B & 1 & 579,4 & 579,4 & 14,68 & $0,004^{*}$ \\
C & 1 & 117,1 & 117,1 & 2,97 & 0,119 \\
D & 1 & 1874,5 & 1874,5 & 47,49 & $0,000^{*}$ \\
E & 1 & 613,3 & 613,3 & 15,54 & $0,003^{*}$ \\
F & 1 & 172 & 172 & 4,36 & 0,066 \\
Eror & 9 & 355,3 & 355,3 & & \\
\hline Total & 15 & 3850,6 & & & \\
\hline Ket: $\left(^{*}\right)$ berbeda nyata pada taraf 0,05
\end{tabular}

Pada hasil anova didapatkan bahwa pengaruh faktor utama yang berbeda nyata adalah factor B (konsentrasi media pelindi), faktor D (persen padatan) dan E (temperatur) karena P-Value < 0,05 . Artinya bahwa faktor yang berpengaruh terhadap persen kadar timbal adalah faktor B, D dan E. sedangkan faktor A (ukuran partikel), C (kecepatan pengadukan) dan F (waktu pelindian) tidak memberikan pengaruh terhadap persen kadar timbal. Hasil analisis ini diperkuat dengan plot pengaruh utama yang diberikan pada Gambar 1.

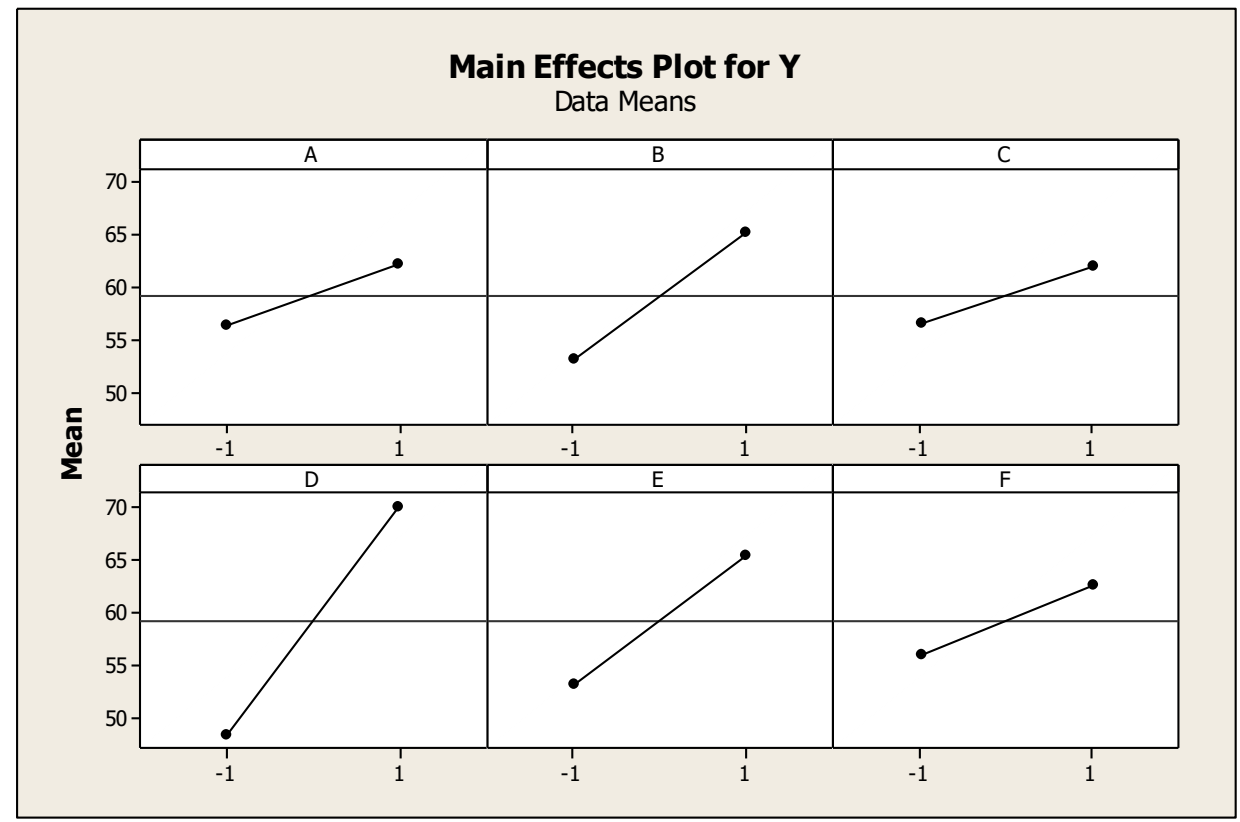

Gambar 1. Plot Pengaruh Utama untuk Ilustrasi Data Percobaan pada Tabel 8

Pada Gambar 1 terlihat bahwa faktor B, D dan E memberikan perbedaan pengaruh yang besar. Karena sifatnya adalah screening experiment maka untuk percobaan lanjutan dapat dilakukan 


\section{Sri Winarni dkk.}

dengan mencobakan tiga faktor ini saja tetapi dengan taraf faktor yang lebih banyak sehingga dapat diketahui komposisi perlakuan yang memberikan respon optimum.

\section{KESIMPULAN}

Kesimpulan yang didapat dari penelitian ini bahwa untuk melakukan percobaan dengan enam faktor dapat dilakukan dengan tiga alternatif sebagai berikut:

a. Alternatif pertama adalah dilakukan dengan desain FF fraksi setengah yang hanya mencobakan 32 kombinasi perlakuan. Dengan desain ini dapat diduga 31 pengaruh faktor yang terdiri dari 6 pengaruh faktor utama, 15 pengaruh interaksi dua faktor dan 6 pengaruh interaksi tiga faktor.

b. Alternatif kedua adalah dilakukan dengan desain FF fraksi seperempat yang hanya mencobakan 16 kombinasi perlakuan. Dengan desain ini dapat diduga 15 pengaruh faktor yang terdiri dari 6 pengaruh faktor utama, 7 pengaruh interaksi dua faktor dan 2 pengaruh interaksi tiga faktor.

c. Alternatif pertama adalah dilakukan dengan desain FF fraksi seperdelapan yang hanya mencobakan 8 kombinasi perlakuan. Dengan desain ini dapat diduga 7 pengaruh faktor yang terdiri dari 6 pengaruh faktor utama, dan 1 pengaruh interaksi dua.

Kesimpulan berikutnya adalah bahwa untuk mengetahui faktor yang berpengaruh dilakukan analisis anova. Pada ilustrasi data percobaan didapatkan kesimpulan bahwa faktor yang berpengaruh terhadap persen ekstrak timbal adalah faktor konsentrasi media pelindi, faktor persen padatan dan faktor temperature. Percobaan lanjutan dapat dilakukan hanya dengan ketiga faktor tersebut.

\section{DAFTAR PUSTAKA}

Box, G.E.P \& Hunter, J.S. (1961) The 2k" Fractional Factorial Designs* Part I. Technometric VOL. 3, No. 3.

Chen, B.J. (1992). Some Result on $2^{n-k}$ Fractional Factorial Design and Search for Minimum Aberration Design. The Annals of Statistics. Vol 20 No 4.

Chen, J. Sun, D.X. \& Wu, C.F.J. (1993). A Catalogue of Two-level and Three-Level Fractional Factorial Designs with Small Runs. Revue Internationale de Statistique, Vol. 61, No. 1

Montgomery, D.C. (1997). Design and Analysis of Experiment. John Wiley \& Son, Inc.

Nair, V. et.all (2008) Screening Experiments and the Use of Fractional Factorial Designs in Behavioral Intervention Research. American Journal of Public Health. Vol 98, No. 8.

Statistika, Vol. 19, No. 2, November 2019 